УДК 622.831

Article / Статья

(C) PNRPU / ПНИПУ, 2017

\title{
RESULTS OF EXPERIMENTAL STUDY OF FRICTION EFFECT ON MECHANICAL PROPERTIES OF SALT ROCKS
}

\section{I.L. Pankov, I.A. Morozov}

Perm National Research Polytechnic University (29 Komsomolskii av., Perm, 614990, Russian Federation)

\section{РЕЗУЛЬТАТЫ ЭКСПЕРИМЕНТАЛЬНОГО ИССЛЕДОВАНИЯ ВЛИЯНИЯ ТРЕНИЯ НА МЕХАНИЧЕСКИЕ ПОКАЗАТЕЛИ СОЛЯНЫХ ПОРОД ${ }^{1}$}

\section{И.Л. Паньков, И.А. Морозов}

Пермский национальный исследовательский политехнический университет (614990, Россия, г. Пермь, Комсомольский пр., 29)

Received / Получена: 06.09.2016. Accepted / Принята: 25.02.2017. Published / Опубликована: 31.03.2017

\section{Key words}

rocks, rock salt, mechanical properties, friction coefficient, friction, strength limit, destruction deformation, specific energy consumption for deformation, uniaxial compression, surface conditions, frontal conditions, Verkhnekamsk deposit of potassium salts, laboratory study, shape coefficient, destruction.

\begin{abstract}
The purpose of the work is to study influence of friction between samples and press plates on mechanical parameters of salt rocks.

The main source of information for determining values of mechanical parameters of salt rocks is laboratory tests of rock samples for compression. It is known that values of mechanical parameters determined from results of compression of samples essentially depend on magnitude of frictional force between fronts and plates of a press. Wherein, empirical coefficients of shape used in calculation of values of mechanical parameters corresponding to uniaxial compression do not take into account specific frontal conditions. This leads to a known inaccuracy in formulation of an experiment and interpretation of its results. Thus, relevant studies correspond to more detailed study of influence of friction between samples and press plates on mechanical properties of salt rocks.

During experimental studies 75 samples of fine to medium grained rock salt from Verkhnekamsk deposit of potassium salts were tested. The paper presents results of experimental studies directed to determine coefficient of friction of salt rocks according to a scheme "shear with compression" over various surfaces. Studies were carried out on compression of samples of different heights under known contact conditions. The necessary friction value was modeled using manufactured gaskets placed between fronts of samples to be tested for compression and press plates. A full diagram of deformation was build from the compression results of each sample and a set of mechanical parameters was determined. Dependences that reflect an effect of frictional forces between fronts of samples and press plates under compression on values of strength limit, destructive deformation and specific energy consumption of rock salt deformation are determined.

Results of the study are intended to improve a method of testing rocks for compression.
\end{abstract}

Целью работы является изучение влияния трения между образцами и плитами пресса на механические показатели соляных пород.

Основным источником информации для определения значений механических показателей соляных пород являются лабораторные испытания породных образцов на сжатие. Известно, что определяемые по результатам сжатия образцов значения механических показателей существенным образом зависят от величины силы трения между торцами и плитами пресса. При этом эмпирические коэффициенты формы, используемые при расчете величин механических характеристик, соответствующих одноосному сжатию, в явном виде не учитывают конкретные торцевые условия. Это приводит к известной неточности в постановке эксперимента и трактовке его результатов. Таким образом, актуальными являются исследования, связанные с более детальным изучением влияния трения между образцами и плитами пресса на механические показатели соляных пород.

В ходе экспериментальных исследований было испытано 75 образцов тонко-среднеслоистой каменной соли Верхнекамского месторождения калийных солей. В работе приведены результаты экспериментальных исследований по определению коэффициентов трения соляных пород по схеме «сдвиг со сжатием» по различным поверхностям. Выполнены исследования сжатия образцов различной высоты при известных контактных условиях. Необходимая величина трения моделировалась использованием специально изготовленных прокладок, размещаемых между торцами испытываемых на сжатие образцов и плитами пресса. По результатам сжатия каждого образца строилась полная диаграмма деформирования и определялся комплекс механических показателей. Получены зависимости, отражающие влияние сил трения между торцами образцов и плитами пресса при сжатии на значения предела прочности, разрушающей деформации, удельной энергоемкости деформирования каменной соли.

Результаты исследования предназначены для совершенствования методики испытания горных пород на сжатие.

Ivan L. Pankov (Author ID in Scopus: 7006961424) - PhD in technical sciences, Associate Professor at the Department of Mineral Deposits Development (tel.: +007342 21637 03, e-mail: ivpan@mi-perm.ru).

Ivan A. Morozov - Assistant Lecturer at the Department of Mineral Deposits Development (tel.: +007 342 219 80 31, e-mail: imorozov.work@yandex.ru).

Паньков Иван Леонидович - кандидат технических наук, доцент кафедры разработки месторождений полезных ископаемых (тел.: +007 3422163703 , e-mail: ivpan@mi-perm.ru).

Морозов Иван Александрович - aссистент кафедры разработки месторождений полезных ископаемых (тел.: +007 342 219 80 31, e-mail: imorozov.work@yandex.ru).

${ }^{1}$ Работа выполнена при финансовой поддержке гранта правительства РФ (постановление правительства РФ № 220 от 09.04.2010). 


\section{Introduction}

To ensure geomechanical mining safety on every stage it is needed to have rock properties data that is based on modern experimental and theoretical methods of its determination. This requirement is especial relevant for Verkhnekamskoe field of potassium salt (VKFPS). Its development requires preservation of waterproof thickness integrity. If it is broken then potassium mine can be accidentally flooded [1].

There are over 80 salt mines flooded and unable to repair. There are some major accidents on the territory of Russia and former USSR that are as follows flooding of mine No. 1 of Iletskoe rock salt deposit, BKPRU-1 and BKPRU-3 mines of VKFPH. During operation of mine No. 1 at Iletskoye field there were multiple water breakthroughs of water and brines into underground mine workings through karst cracks and voids. For example, with next breakthrough of salt water on February 17, 1979 a mine No. 1 was flooded. Mine BKPRU-3 was flooded in July 1986. Salt leaching over a block No. 8 led to collapse of ground surface. A gap of $60-80 \mathrm{~m}$ and width of 40-50 m was formed. In October 2006, a brine breakthrough occurred in BKPRU-1 mine, which led to its accidental flooding. A retrospective analysis of accidents at mining companies that develop water-soluble ores allows to say that in general an accident is caused by the fact that parameters of a development system do not correspond to conditions of particular conditions of developing segments. Thus, it is necessary that parameters of development system have to correspond to geological conditions of particular segments with consideration of physical and mechanical properties of formations of interest [2].

During calculation of parameters of development system, one of the main indicators of stability of mines is ultimate strength for uniaxial compression. But, despite the fact that GOST 21153.2-84 [3] describes conditions for laboratory tests for strength of samples, it is not always possible to carry out an experiment in accordance with established requirements for mass tests of salt rocks. According to studies of M. Kulbauf [4], nature of deformation and a value of compressive strength significantly change when adhesion at contacts of a sample under press plates decreases, in particular, when using gaskets lubricated with graphite. For example, for cubic samples of rock salt with a face length of $5 \mathrm{~cm}$, a value of tensile strength decreases in 2 times. When testing cubic samples of rock salt with a face size of $10 \mathrm{~cm}$ it was established by F.V. Uhlenbeker [4] that an increase in compressive strength was $40.3 \mathrm{MPa}$ in comparison with $31 \mathrm{MPa}$ for samples with no gaskets. It is mentioned by R. Kwapila in a reference [4] that lubrication on pressure planes reduces a value of tensile strength by $30-50 \%$. It is noted that use of various types of lubricant on contacts of a sample with press plates during compression tests leads to a significant decrease in tensile strength. Intensity of decrease of sample strength depends on a ratio of vertical and transverse dimensions of samples. For high samples, with height to side length ratio or a sample diameter of more than 3, contact conditions have practically no effect on a strength value [4]. In [5], to evaluate effect of contact conditions on strength and deformation properties of samples of salt rocks, samples of variegated sylvinite were tested in dry friction mode and when thin sheets of fluoroplastic $0.1 \mathrm{~mm}$ thick were used as liners, which were installed between the ends of a sample and plates of a press. Application of PTFE gaskets contributed to decrease in tensile strength, destructive deformation, deformation modulus, decline modulus. According to [5] intensity of influence of gaskets depends on a ratio of height of a sample to its diameter. M.F. Kuntysh [4] notes a regular decrease in strength when grinding and polishing surfaces of samples. I.V. Baklashev [6] points out that the lack of adhesion at the ends reduces strength of uniaxial compression by 30 $50 \%$. In [7-9], authors note that the lower a coefficient of friction between the ends of salt samples tested for compression and press plates the lower tensile strength, deforming strain, specific energy intensity of deformation and the higher a modulus of decay are observed. For example, with ratio of height of a sample to its diameter of 0.75 and increase in coefficient of static friction from 0.1 to 0.5 a value of tensile 
strength increases from 22 to $36 \mathrm{MPa}$. In this case, destructive deformation increases from 3 to $7 \%$, specific energy intensity of deformation is from 0.5 to $4.5 \mathrm{MJ} / \mathrm{m}^{3}$. Increase in a ratio of height to diameter from 0.75 to 1.50 leads to a decrease in effect of a coefficient of friction on the values of the ultimate strength, destructive deformation, and specific energy intensity of deformation. For samples with a height to diameter ratio of 1.50 , increase in a coefficient of friction from 0.1 to 0.5 entails an increase in avalue of tensile strength from 20 to $24 \mathrm{MPa}$, which destroys deformation from 2 to $3 \%$, specific energy intensity of deformation is from 0.5 to $1.0 \mathrm{MJ} / \mathrm{m}^{3}$. With an increase in a ratio of height to diameter of a sample from 0.75 to 1.50 there is an increase in decay modulus is observed. If a height to diameter ratio is 0.75 , then with increasing friction coefficient is from 0.1 to $0.5 \mathrm{a}$ decay modulus varies from 0.8 to $0,4 \mathrm{GPa}$, and with a height to diameter ratio of 1.50 it varies from 1.6 to $0.8 \mathrm{GPa}$.

Summarizing results of studies [4-12], it can be said that values of tensile strength, destructive strain, decay modulus and specific energy intensity of deformation, obtained during compression, depend to a large extent on magnitude of frictional force between sample ends and press plates. At the same time, it decreases its influence on obtained values of mechanical characteristics with increase in sample height [13-16].

There is a number of ways to reduce influence of friction on values of obtained parameters of rock mechanical properties such as increasing the sample height, using samples of special shape, lubricating contact surfaces, applying load plates of the same diameter as the test sample etc. Each of these methods has its drawbacks. The higher the sample the lower its stability and more corrupted results of experiments. Besides, production of higher samples during mass tests leads to sharp increase in rock material consubption, which can cause some difficulties in production of required number of samples. Lubricant can lead to distortion of experimental data due to a possibility of its penetration into rock with subsequent wedging of a sample. Use of special-shaped samples is difficult due to complexity of their manufacture. Use of load plates of the same diameter as a sample also did not find wide application because of labor intensity of experiment.

In real conditions during determination of ultimate strength of rocks, empirical shape coefficients are used $[4,5,10,17,18]$, which allow to consider inhomogeneity of stress state in a sample under compression. Coefficients used do not take into account magnitude of the frictional force between ends of samples and the plates of the press, which leads to a certain inaccuracy in the experiment and interpretation of its results. Thus, it is relevant to study in detail influence of friction force between samples and plates of press on mechanical parameters of salt rocks.

\section{Experimental studies of friction}

There were two stages of the study: 1st determination of friction coefficients of salt rocks on different surfaces; 2nd - carrying out experimental studies on compression of samples of different heights at known values of friction coefficient.

To determine friction coefficients 15 prismatic samples in $20 \times 70 \times 70 \mathrm{~mm}$ in size were manufactured from monolith thin-medium-bedded rock salt, taken from VKFPS. Samples were made with no washing liquid on special stone cutting equipment. Deviation of sample faces from the surface was not biger than $0.02 \mathrm{~mm}$, from parallelism $-0.10 \mathrm{~mm}$, from the perpendicularity $0.50 \mathrm{~mm}$. Before the test, all samples were kept in a drying oven at temperature of $90{ }^{\circ} \mathrm{C}$ until a constant weight was achieved.

Friction experiments were carried out according to a scheme "shear with compression" on multipurpose test complex MTS 816 (Fig. 1) for three types of contacts such as "salt-polymer", "saltmetal", "salt-abrasive material". The MTS 816 is equipped with a servo-hydraulic drive. A frame has rigidity of $1.1 \cdot 10^{9} \mathrm{~N} / \mathrm{m}$. Maximum compressive/ tensile force is $496 / 291 \mathrm{kN}$. Maximum shear force is $261 \mathrm{kN}$. The test complex is equipped with a high-precision system for measuring linear movements of compression/tension and has accuracy of $0.001 \mathrm{~mm}$. The system has four vertical and two horizontal sensors for measuring normal and shear strains, as well as tilt of samples during a test with an accuracy of $0.001 \mathrm{~mm}$. 


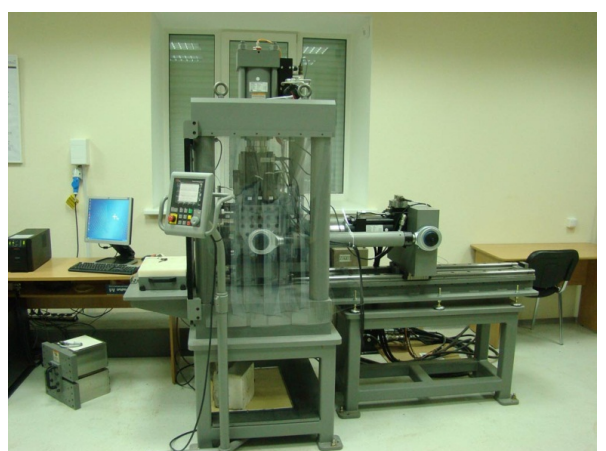

Fig. 1. Multi-purpose test Complex MTS 816

To study a contact "salt-metal" smooth metal plates of $8 \mathrm{~mm}$ in thickness were made. Abrasive grade 14A SFJU1C was used as abrasive material. Viniplast plates of $2 \mathrm{~mm}$ in thickness with graphite grease were used as a polymer. Before the friction test a sample was fixed in a lower matrix of a test installation by a solution of magnesia cement. Test materials such as viniplast, metal or abrasive plates were rigidly attached to an upper matrix. Each sample got a series of experiments with different values of vertical loads. The sample was loaded in test complex in accordance to scheme given in Fig. 2.

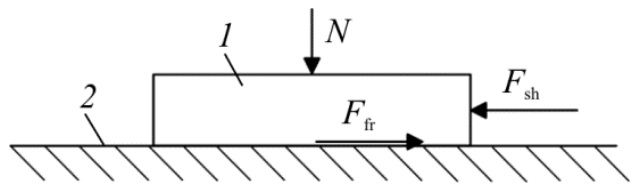

Fig. 2. Scheme of sample loading in test complex MTS 816 when determining friction coefficients: 1 - a sample of rock salt; 2 - friction surface (polymer, metal, abrasive). $N$ - vertical force; $F_{\mathrm{fr}}-$ force between a sample and tested material; $F_{\text {sh }}-$ share force
According to results of tests of each sample, friction force $F_{f r}$ between tested material and sample's end was plotted versus displacement $h$ of a sample (Fig. 3).

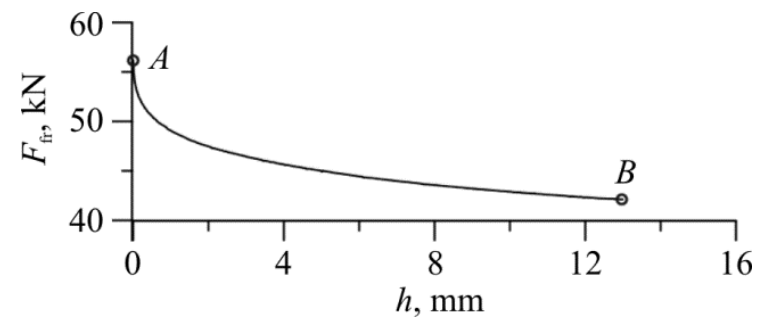

Fig. 3. Dependence of friction force $F_{f r}$ on displacement $h$ of a sample: A and B are the points corresponding to the frictional forces of static and sliding

Determination of coefficient of static friction $\mu$ that corresponds to peak value of frictional force (point $A$, Fig. 3), which impedes the motion during the beginning of movement of a sample along tested material, was carried out according to the law of Amonton [19]:

$$
\mu=F_{f r} / N
$$

where $N$ - vertical force that is applied to a sample in test installation, $\mathrm{kN} ; F_{\mathrm{fr}}$ - friction force between a sample and tested material, that corresponds to a force (coefficient) of static friction (point $A$, Fig. 3), kN.

Then experimental data was processed through plotting regression functions of friction coefficients versus magnitude of a vertical force for all types of contacts (Fig. 4).
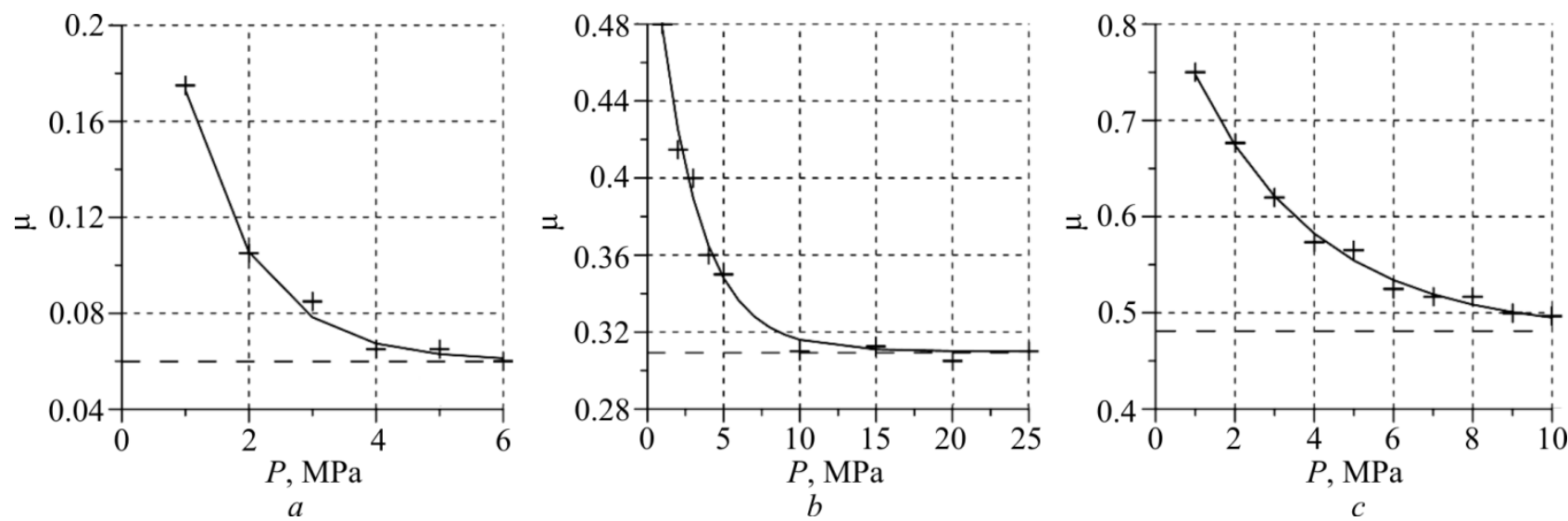

Fig. 4. Function of static friction coefficient versus vertical force:

$a$ - for «salt - polymer» contact; $b$ - for «salt - metal» contact; $c$ - for «salt - abrasive» contact 
Analysis of experimental data (see Fig. 4) by the method described in [20] showed that a function of friction coefficient $\mu$ versus vertical force $P, \mathrm{MPa}$, for contact types studied can be represented as

$$
\mu=a+\exp (b+c P),
$$

where $a, b, c$ - approximation parameters.

Required values of friction coefficients (Table 1) were determined in a form of corresponding asymptotes of a function (2).

Table 1

Values of friction coefficients for different types of contacts

\begin{tabular}{|l|c|}
\hline \multicolumn{1}{|c|}{ Contact type } & $\mu$ \\
\hline Salt - polymer & $0.05-0.07$ \\
\hline Salt - metal & $0.30-0.32$ \\
\hline Salt - abrasive & $0.46-0.50$ \\
\hline
\end{tabular}

\section{Results and analysis of compression of salt samples}

For compression experiments there were three batches of samples manufactured. Each batch included 20 pieces made from fine to medium bedded rock salt of VKFPS with a height to width ratio of $0.75,1.25$ and 1.75 . Deviation of sample facies from flatness was less than $0.02 \mathrm{~mm}$, from parallelism $-0.10 \mathrm{~mm}$, from perpendicularity $0.50 \mathrm{~mm}$. Prior to a compression test all samples were kept in a drying cabinet at a temperature of $90{ }^{\circ} \mathrm{C}$ until a constant weight was achieved. Compression experiments were performed on a Zwick/Z250 press (Fig. 5) under a rigid loading regime with a constant deformation rate at various friction coefficients between sample ends and press plates. An installation Zwick/Z250 has an electromechanical drive type. The maximum tensile/compression force is $250 \mathrm{KN}$. Speed of traverse movement is $0.001-600 \mathrm{~mm} / \mathrm{min}$. A machine is equipped with a movement sensor of $0.001 \mathrm{~mm}$ accuracy.

Necessary frictional compression value was simulated by use of viniplast, metal or abrasive gaskets placed between ends of compression-tested samples and press plates. During compression of samples a machine recorded acting force $\mathrm{N}, \mathrm{N}$ and corresponding deformations $l^{\prime}$ in real time, $\mathrm{mm}$. "True" sample deformations $l, \mathrm{~mm}$ were determined taking into account press deformability (compliance):

$$
l=l^{\prime}-a_{1} N^{b_{1}},
$$

where $a_{1}, b_{1}-$ approximation parameters, which were determined after test of each sample according to results of loading of a metal cylinder. It was assumed that deformations of a cylinder are negligibly small and deformations recordered by a machine correspond to deformations of a test installation only.

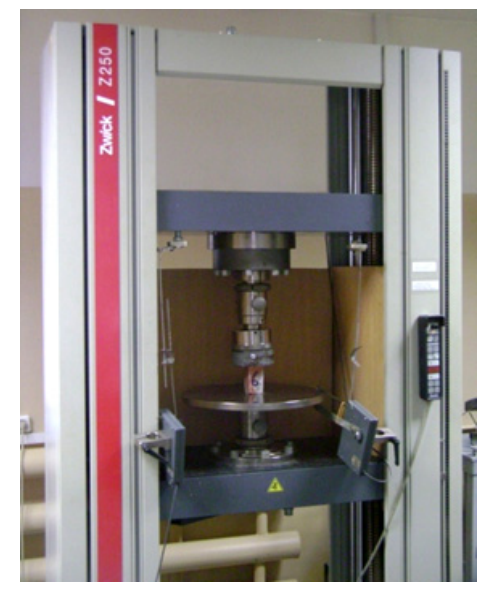

Fig. 5. Testing machine Zwick/Z250

After "true" deformations were determined, a full deformation diagram was built for each sample in coordinates "stress versus relative longitudinal deformation". A set of mechanical parameters such as ultimate strength, breaking deformation, specific energy intensity of deformation was determined. A typical deformation diagram is shown in Fig. 6.

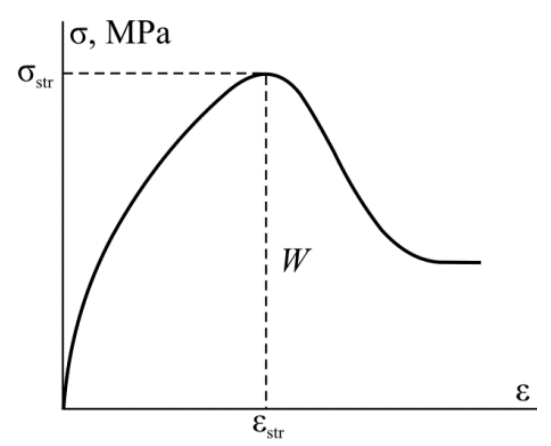

Fig. 6. Typical deformation diagram built in coordinates "stress versus relative longitudinal deformation": $\sigma$ - stress, $\mathrm{MPa} ; \varepsilon$ - relative longitudinal deformation; $\sigma_{\text {str }}-$ ultimate strength, $\mathrm{MPa} ; \varepsilon_{\text {str }}$ - destructive deformation; W - specific energy intensity of deformation, $\mathrm{MJ} / \mathrm{m}^{3}$ 
The ultimate strength was defined as the greatest stress that can be absorbed by a sample (see Fig. 6). Destructive deformation is a deformation corresponding to a strength limit. Specific energy intensity of deformation was determined in a form of area bounded by a deformation diagram and axis of longitudinal deformations.

Based on results of experimental studies, functions of tensile strength, destructive deformation, specific energy intensity of deformation versus coefficient of friction and ratio of height to cross size of samples tested for compression were obtained (Fig. 7).

Analysis of experimental data showed that values of ultimate strength, destructive deformation, specific energy intensity of deformation, obtained by compression of samples of different heights, depend significantly on frictional forces between sample ends and press plates. Herewith, the smaller a ratio of height to cross size the higher friction effect.
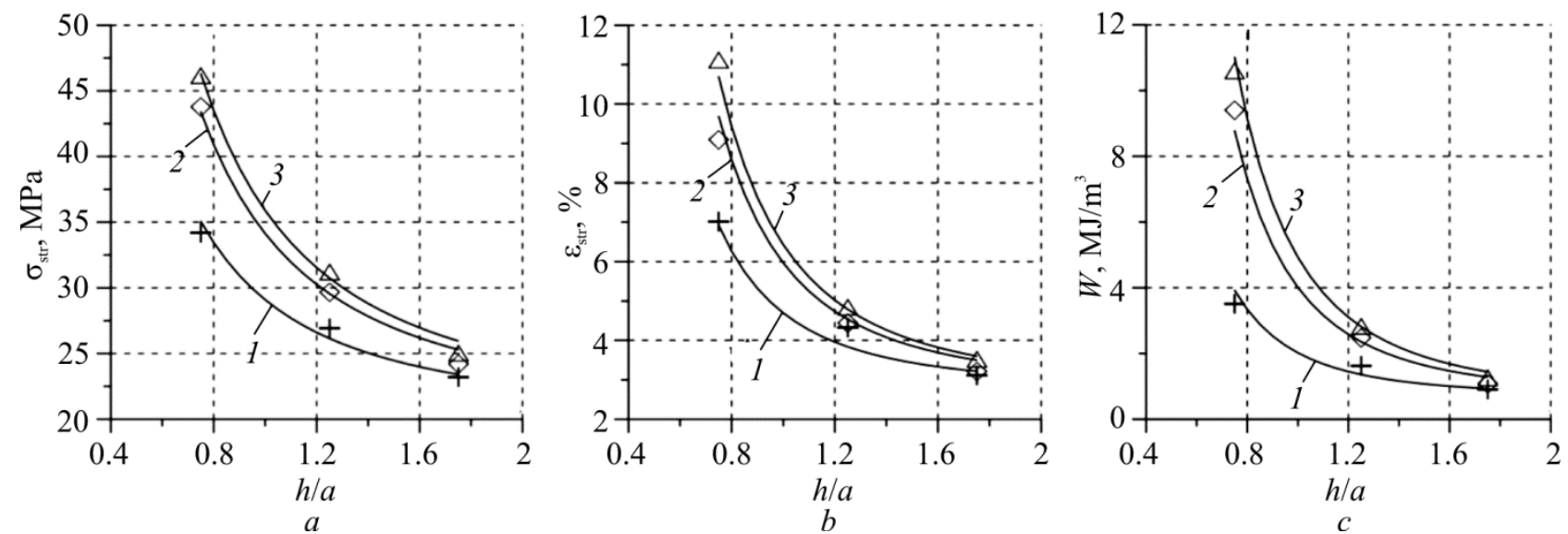

Fig. 7. Results of experimental studies of influence of friction coefficient during compression of samples of different heights on values of mechanical parameters: $a$-ultimate strength;

$b$-destructive deformation; $c$-specific energy intensity of deformation. $1,2,3$ are functions obtained during compression at the contact "salt-polymer", "salt-metal", "salt-abrasive"

Thus, if a coefficient of friction between end faces of a sample and press plates equals to 0.48 , during increase in a ratio of height to cross size of test sample from 0.75 to 1.75 there is a decrease in values of mechanical parameters such as $44 \%$ for strength limit, $66 \%$ for destructive deformation, $87 \%$ specific energy intensity of deformation. If a coefficient of friction between ends of a sample and press plates is reduced from 0.48 to 0.06 and a ratio of height of test sample to cross size is increased from 0.75 to 1.75 then there is a decrease in values of strength limit by $33 \%$, destructive deformation by $53 \%$ and specific energy intensity of deformation by $76 \%$ observed. Thus, it should be noted that if a ratio of height to cross size of compressed samples equals 2 or more (see Fig. 7), the effect of friction on obtained values of mechanical parameters can be neglected. Use of compression data of "short" samples, with a ratio of height to cross size less than 2, with no correction factors used in geomechanical calculations of load-bearing elements of a development system can lead to overestimation of their strength and deformation characteristics. As a result that could lead to an accident in a potash mine. The results obtained match satisfactorily with data of other studies.

It was found that in order to determine ultimate strength $\sigma_{0}, \mathrm{MPa}$, destructive deformation $\varepsilon_{0}$, specific energy intensity of deformation $\mathrm{W}_{0}$, $\mathrm{MJ} / \mathrm{m}^{3}$ that correspond to uniaxial compression following equations can be used

$$
\begin{gathered}
\sigma_{0}=\frac{\sigma_{\text {str }}}{\left(1+d_{1} \mu^{e_{1}} m^{f_{1}}\right)}, \\
\varepsilon_{0}=\frac{\varepsilon_{\text {str }}}{\left(1+d_{2} \mu^{e_{2}} m^{f_{2}}\right)}, \\
W_{0}=\frac{W}{\left(1+d_{3} \mu^{e_{3}} m^{f_{3}}\right)},
\end{gathered}
$$


where $\sigma_{\text {str }}, \varepsilon_{\text {str }}, W$ - values of tensile strength, MPa, destructive deformation, specific energy intensity of deformation, $\mathrm{MJ} / \mathrm{m}^{3}$, obtained from results of compression of samples with a ratio of height to cross size $m$ at a coefficient of friction between ends and plates of a press $\mu ; d_{1}, e_{1}, f_{1}, d_{2}, e_{2}, f_{2}, d_{3}$, $e_{3}, f_{3}$ - approximation parameters.

Equations (4)-(6), which determine values of mechanical parameters under uniaxial compression, taking into account shape of a sample and friction value at contacts, can be represented as

$$
X_{0}=\frac{X}{1+d \mu^{e} m^{f}},
$$

where $X-$ values of tensile strength, MPa, destructive deformation, specific energy intensity of deformation, $\mathrm{MJ} / \mathrm{m}^{3}$, obtained from results of compression of samples with a ratio of height to cross size $m$ at a coefficient of friction between ends and plates of a press $\mu ; d, e, f-$ approximation parameters (Table 2).

Table 2

\section{Approximation parameters}

\begin{tabular}{|l|c|c|c|}
\hline \multicolumn{1}{|c|}{ Mechanical parameter } & $d$ & $e$ & $f$ \\
\hline Tensile strength, MPa & $0.9 \ldots 1.0$ & $0.2 \ldots 0.3$ & $-1.9 \ldots-1.6$ \\
\hline Destructive deformation, $\%$ & $1.5 \ldots 1.8$ & $0.3 \ldots 0.4$ & $-3.0 \ldots-2,4$ \\
\hline $\begin{array}{l}\text { Specific energy intensity of } \\
\text { deformation, } \mathrm{MJ} / \mathrm{m}^{3}\end{array}$ & $8.1 \ldots 10.2$ & $0.5 \ldots 0.6$ & $-3.4 \ldots-2.8$ \\
\hline
\end{tabular}

\section{Conclusion}

During the research a detailed analysis of references on the corresponding issue was carried out. Thanks to an analysis of results of other studies it is possible to conclude that there is a need of more detailed study of friction effect on values of mechanical parameters of salt rocks, determined by results of compression of samples.

For an experimental part of the research there were prismatic samples of various heights made of a rock salt monolith of VKFPS on special stone cutting equipment. No washing liquid was used. At the first stage of the study coefficients of friction of salt rocks on different surfaces were determined. At the same time, various end conditions were modeled by gaskets made of vinyl plastic, metal and abrasive material. Friction experiments are performed on a high-precision test complex MTS 816 in the "shear with compression" scheme for various vertical loads. At the second stage of the study a set of experiments was performed to compress salt samples of different heights on an electromechanical press Zwick/Z250 with in advance defined end conditions in the form of friction coefficients. According to results of compression experiments, functions that reflect the effect of frictional forces (between ends of samples and pres plates during compression) on values of mechanical properties of salt rocks such as ultimate strength, destructive deformation, specific energy intensity of deformation were obtained. Presented relationships allow taking into account influence of end conditions on values of mechanical parameters of salt rocks, determined by results of compression of rock samples in laboratory conditions.

Results of the study are intended to improve the method of testing of rocks for compression.

\section{References}

1. Laptev B.V. Istoriografiia avarii pri razrabotke solianykh mestorozhdenii [Historiography of accidents in the development of salt deposits]. Bezopasnost' truda $v$ promyshlennosti, 2011, no.12, pp.41-46.

2. Coates D.F. Classification of rocks for rock mechanics. International Journal of Rock Mechanics and Mining Sciences, 1964, vol. 1, iss. 3, p. 421-429. DOI: 10.1016/0148-9062(64)90008-7

3. GOST 21153.2-84. Porody gornye. Metody opredeleniia predela prochnosti pri odnoosnom szhatii [Mountain rocks. Methods for determining the ultimate strength under uniaxial compression]. Moscow, Izdatel'stvo standartov, 1985, $10 \mathrm{p}$.

4. Proskuriakov N.M., Permiakov R.S., Chernikov A.K. Fiziko-mekhanicheskie svoistva solianykh porod [Physical and mechanical properties of salt rocks]. Leningrad, Nedra, 1973. - $271 \mathrm{c}$.

5. Bariakh A.A, Asanov V.A., Pan'kov I.L. Fizikomekhanicheskie svoistva solianykh porod Verkhnekamskogo kaliinogo mestorozhdeniia [Physical and mechanical properties of salt rocks of the Verkhnekamsk potash deposit]. Perm', Izdatel'stvo Permskogo gosudarstvennogo tekhnicheskogo universiteta, 2008, $199 \mathrm{p}$.

6. Baklashov I.V. Geomekhanika. Vol. 1. Osnovy geomekhaniki [Geomechanics. Vol. 1. Fundamentals of Geomechanics]. Moscow, Izdatel'stvo Moskovskogo gosudarstvennogo gornogo universiteta, 2004, 208 p.

7. Pan'kov I.L., Morozov I.A. Study of the friction coefficient influence on salt rocks mechanical indicators in sample compression of varying heights. Bulletin of Perm 
National Research Polytechnic University. Geology. Oil \& Gas Engineering \& Mining, 2013, no.7, pp.57-67.

8. Morozov I.A. Eksperimental'noe issledovanie vliianiia koeffitsienta treniia na znacheniia pokazatelei mekhanicheskikh svoistv solianykh porod pri szhatii obraztsov razlichnoi vysoty [An experimental study of influence of coefficient of friction on values of indexes of mechanical properties of salt rocks with compression of samples of different heights]. Problemy razrabotki mestorozhdenii uglevodorodnykh $i$ rudnykh poleznykh iskopaemykh. Materialy VII Vserossiiskoi konferentsii. Perm', Izdatel'stvo Permskogo natsional'nogo issledovatel'skogo politekhnicheskogo universiteta, 2014, pp.397-400.

9. Pan'kov I.L., Morozov I.A. Issledovanie vliianiia koeffitsienta treniia mezhdu tortsami obraztsov razlichnoi vysoty i plitami pressa na mekhanicheskie pokazateli solianykh porod [Investigation of the influence of the coefficient of friction between the ends of samples of different heights and press plates on the mechanical properties of salt rocks]. Izvestiia vysshikh uchebnykh zavedenii. Gornyi zhurnal, 2015, no.2, pp.107-113.

10. Kartashov Iu.M., Matveev B.V., Mikheev G.V., Fadeev A.B. Prochnost' i deformiruemost' gornykh porod [Strength and deformability of rocks]. Moscow, Nedra, 1979, 269 p.

11. Peng S.D. Stresses within elastic circular culinders loaded uniaxially und triaxially. International Journal of Rock Mechanics and Mining Sciences \& Geomechanics Abstracts, 1971, vol.8, iss.5, p.399-432. DOI: 10.1016/1365-1609(71)90009-8

12. Barton N.R. A model study of rock-joint deformation. International Journal of Rock Mechanics and Mining Sciences \& Geomechanics Abstracts, 1972, vol.9, iss.5, pp.579-582. DOI: 10.1016/0148-9062(72)90010-1

13. Pan'kov I.L., Asanov V.A., Udartsev A.A., Kuz'minykh V.S., Evseev V.S. Osobennosti deformirovaniia i razrusheniia solianykh porod [Features of deformation and fracture of salt rocks]. Problemy bezopasnosti $i$ effektivnosti osvoeniia georesursov $v$ sovremennykh usloviiakh: materialy nauchnoprakticheskoi konferentsii. Perm', 2014, pp.304-311.

14. Dreyer W. Die Bedeutung von modellversuchen an salzgesteinen für die beurteilung gebursmechanischer probleme im kalibergbau. Bergakademia, 1964, no.16.

15. Mogi K. Some precise measurements of fracture strength of rocks under uniform compressive strength. Rock Mechanics Engineering Geology, 1966, no.4, pp.41-55.

16. Hudson J.A., Brown E.T., Rummel F. The controlled failure of rock discs and rings loaded in diametral compression. International Journal of Rock Mechanics and Mining Sciences \& Geomechanics Abstracts, 1972, vol.9, iss.2, pp.241-244. DOI: 10.1016/0148-9062(72)90025-3

17. Borshch-Komponiets V.I. Prakticheskaia mekhanika gornykh porod [Practical mechanics of rocks]. Moscow, Gornaia kniga, 2013, 322 p.

18. Ukazaniia po zashchite rudnikov ot zatopleniia $\mathrm{i}$ okhrane podrabatyvaemykh ob"ektov v usloviiakh Verkhnekamskogo mestorozhdeniia kaliinykh solei (tekhnologicheskii reglament) [Guidelines for the protection of mines from flooding and protection of work-in-process facilities in Verkhnekamsk deposit of potash salts (process regulations)]. Saint Petersburg, 2008, $101 \mathrm{p}$.

19. Penkin N.S., Penkin A.N., Serbin V.M. Osnovy tribologii i tribotekhniki [Fundamentals of tribology and tribotechnics]. Moscow, Mashinostroenie, 2008, 206 p.

20. Vukolov E.A. Osnovy statisticheskogo analiza. Praktikum po statisticheskim metodam i issledovaniiu operatsii s ispol'zovaniem paketov Statistica i Excel [Fundamentals of statistical analysis. A workshop on statistical methods and research on operations using Statistica and Excel packages]. Moscow, Forum, 2008, 464 p.

\section{Библиографический список}

1. Лаптев Б.В. Историография аварий при разработке соляных месторождений // Безопасность труда в промышленности. - 2011. - № 12. - С. 41-46.

2. Coates D.F. Classification of rocks for rock mechanics // International Journal of Rock Mechanics and Mining Sciences. - 1964. - Vol. 1, iss. 3. - P. 421-429. DOI: $10.1016 / 0148-9062(64) 90008-7$

3. ГОСТ 21153.2-84. Породы горные. Методы определения предела прочности при одноосном сжатии. - М.: Изд-во стандартов, 1985. - 10 с.

4. Проскуряков Н.М., Пермяков Р.С., Черников А.К. Физико-механические свойства соляных пород. - Л.: Недра, 1973. - 271 с.

5. Барях А.А., Асанов В.А., Паньков И.Л. Физикомеханические свойства соляных пород Верхнекамского калийного месторождения: учеб. пособие. - Пермь: Издво Перм. гос. техн. ун-та, 2008. - 199 с.
6. Баклашов И.В. Геомеханика: учеб. для вузов: в 2 т. Т. 1. Основы геомеханики. - М.: Изд-во Моск. гос. горн. ун-та, 2004. - 208 с.

7. Паньков И.Л., Морозов И.А. Изучение влияния коэффициента трения на механические показатели соляных пород при сжатии образцов различной высоты // Вестник Пермского национального исследовательского политехнического университета. Геология, нефтегазовое и горное дело. - 2013. - № 7. - С. 57-67.

8. Морозов И.А. Экспериментальное исследование влияния коэффициента трения на значения показателей механических свойств соляных пород при сжатии образцов различной высоты // Проблемы разработки месторождений углеводородных и рудных полезных ископаемых: материалы VII Bсерос. конф. Пермь: Изд-во Перм. нац. исслед. политехн. ун-та, 2014. - C. $397-400$ 
9. Паньков И.Л., Морозов И.А. Исследование влияния коэффициента трения между торцами образцов различной высоты и плитами пресса на механические показатели соляных пород // Известия высших учебных заведений. Горный журнал. - 2015. - № 2. - С. 107-113.

10. Прочность и деформируемость горных пород / Ю.М. Карташов, Б.В. Матвеев, Г.В. Михеев, А.Б. Фадеев. - М.: Недра, 1979. - 269 с.

11. Peng S.D. Stresses within elastic circular culinders loaded uniaxially und triaxially // International Journal of Rock Mechanics and Mining Sciences \& Geomechanics Abstracts. - 1971. - Vol. 8, iss. 5. - P. 399-432, DOI: 10.1016/1365-1609(71)90009-8

12. Barton N.R. A model study of rock-joint deformation // International Journal of Rock Mechanics and Mining Sciences \& Geomechanics Abstracts. - 1972. - Vol. 9, iss. 5. - P. 579-582. DOI: 10.1016/0148-9062(72)90010-1

13. Особенности деформирования и разрушения соляных пород / И.Л. Паньков, В.А. Асанов, А.А. Ударцев, В.С. Кузьминых, В.С. Евсеев // Проблемы безопасности и эффективности освоения георесурсов в современных условиях: материалы науч.-практ. конф. - Пермь, 2014. - C. 304-311.

14. Dreyer W. Die Bedeutung von modellversuchen an salzgesteinen für die beurteilung gebursmechanischer probleme im kalibergbau // Bergakademia. - 1964. - № 16.
15. Mogi K. Some precise measurements of fracture strength of rocks under uniform compressive strength // Rock Mechanics Engineering Geology. - 1966. - № 4. P. 41-55.

16. Hudson J.A., Brown E.T., Rummel F. The controlled failure of rock discs and rings loaded in diametral compression // International Journal of Rock Mechanics and Mining Sciences \& Geomechanics Abstracts. - 1972. - Vol. 9, iss. 2. - P. 241-244. DOI: 10.1016/0148-9062(72)90025-3

17. Борщ-Компониец В.И. Практическая механика горных пород. - М.: Горная книга, 2013. - 322 с.

18. Указания по защите рудников от затопления и охране подрабатываемых объектов в условиях Верхнекамского месторождения калийных солей (Технологический регламент): согласованы письмом Ростехнадзора № 13-13/1218 от 30.04.2008 г. - СПб., 2008. - $101 \mathrm{c}$.

19. Пенкин Н.С., Пенкин А.Н., Сербин В.М. Основы трибологии и триботехники: учеб. пособие. М.: Машиностроение, 2008. - 206 с.

20. Вуколов Э.А. Основы статистического анализа. Практикум по статистическим методам и исследованию операций с использованием пакетов Statistica и Excel: учеб. пособие. - М.: Форум, 2008. - 464 c.

Please cite this article in English as:

Pankov I.L., Morozov I.A. Results of experimental study of friction effect on mechanical properties of salt rocks. Bulletin of PNRPU. Geology. Oil \& Gas Engineering \& Mining, 2017, vol.16, no.1, pp.64-72. DOI: 10.15593/2224-9923/2017.1.7

Просьба ссылаться на эту статью в русскоязычных источниках следующим образом:

Паньков И.Л., Морозов И.А. Результаты экспериментального исследования влияния трения на механические показатели соляных пород // Вестник Пермского национального исследовательского политехнического университета. Геология. Нефтегазовое и горное дело. - 2017. - Т.16, №1. - C.64-72. DOI: 10.15593/2224-9923/2017.1.7 